\title{
Exodus of clergy: 'When the fight is just not worth it anymore' - The role of conflict in responding to the call
}

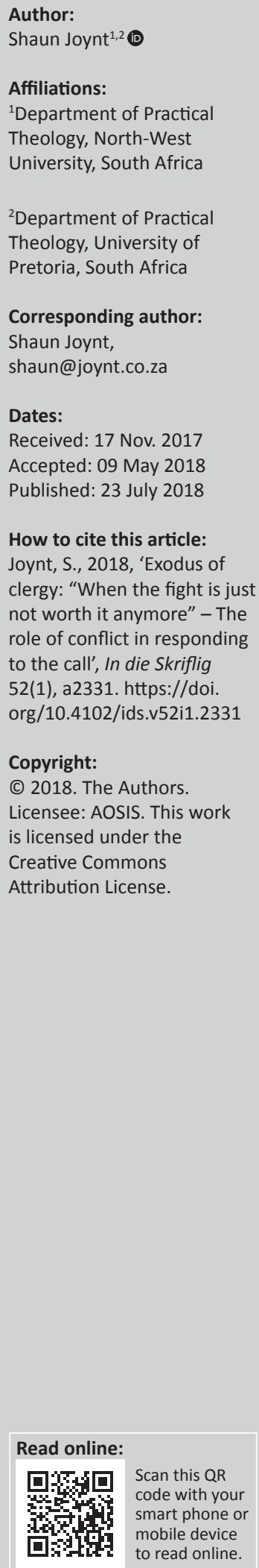

Conflict affects clergy's response to the call. Unresolved conflict negatively influences their decision to remain in full-time pastoral ministry. This contributes to a shortage of clergy in the Roman Catholic Church, but to a lesser extent, the Protestant church, as it faces a distribution or displacement challenge. The shortage negatively affects the church, as clergy equip congregants to live the faith and transmit it to the next generation. The purpose of this study is to discover what factors are involved in responding to the call to full-time pastoral ministry. A practical theological grounded theory approach is used to discover the properties of the basic social process responding to the call and more specifically one of its categories, namely conflict. Semi-structured interviews are conducted and data coded, using Glaser and Strauss' grounded theory methodology in order to determine a basic social process, namely responding to the call. The category of 'conflict' includes properties such as conflict due to lack of communication, dealing with favouritism, conflict with leadership and managing conflict or leaving due to conflict. Osmer's descriptive-empirical task is used to view the category conflict from a practical theological perspective. The results of this study indicate three responses to the call by clergy who left full-time pastoral ministry: not called in the first place, a dual call (being bi-vocational or seasonal), and being called, but leaving anyway due to, among other factors, conflict.

\section{Introduction}

There is a shortage of clergy throughout the world and conflict is one of the factors that contribute to the decision by clergy to discontinue with their call in full-time pastoral ministry (Rainer 2016). The basic social process of responding to the call is 'discovered' by means of a classic grounded theory exploration (Joynt 2012). Various categories contribute to the overall theme with conflict being a sub-theme and the focus of this article. Clergy's interaction with influential and powerful people, whether priests, bishops, campus pastors, senior pastors, denominational representatives or congregants, contributes to their decision to leave or remain in their call to full-time pastoral ministry.

\section{A clergy shortage}

Clergy fulfil particular responsibilities within the church as an organisation (Heitink 2007:19). They foster its spiritual and numerical growth by equipping members in their relation to God, to one another and to those around them. A shortage of clergy will affect these outcomes unfavourably. At present, there is a growing shortage of clergy in both the Roman Catholic and the Protestant church (Carroll 2006:14). Various factors contribute to this decline, namely a change in vocation, forced terminations and sexual misconduct (Cousins 2010:53-54), marital and family challenges, conflict (personal, congregational and denominational), financial issues, and feelings of burnout and frustration (Carroll 2006:167-169; Hoge \& Wenger 2005:49; see Percy 2006:26-29). In addition to these, changes in the roles and responsibilities of clergy also contribute to clergy role confusion (Cahall 2012:92-115) that creates uncertainty in not only what to do, but whom to serve, namely God, the congregation, or individuals (Trull \& Carter 2004:22).

\section{Clergy shortage in the Roman Catholic Church}

The Roman Catholic Church has been experiencing a shortage of priests, both diocesan and religious, since the 1970s, in comparison to the Roman Catholic population that has doubled during the same time (Center for Applied Research in the Apostolate 2015; cf. Mohler 2016). This shortage has been partially mitigated by both an increase in permanent deacons (Center for Applied Research in the Apostolate 2015) and the training of parishioners for lay ministry (The Scotsman 2016). The priest shortage extends to Ireland (The Irish Times 2014), Germany (Salden 
2013), the United States (Catholic Online 2015), Brazil, France, England and Wales (Future Church 2013).

\section{Clergy shortage in the Protestant church}

To a lesser extent, the Protestant church is also facing a shortage of clergy, particularly in the Anglican Church, United Methodist Church, and Assemblies of God (Milbank 2008:128). The United Church of Christ within the US expect a serious clergy shortage as well as a decline in congregation member size within the next six years (Russell 2016). Within South Africa, the Dutch Reformed Church (DRC) expect a clergy shortage within the next eight years and currently utilise retired clergy to serve in local congregations (De Villiers 2010:8). This growing clergy shortage has also been a personal observation of the author. However, recent reports indicate that there may be a turnaround in the shortage of DRC clergy in South Africa as congregations are downsizing due to a decrease in membership and income, thus retrenching clergy as in the case of the DRC Moreleta Park, Pretoria, South Africa, who retrenched 19 staff members, including three clergy (Slatter 2017). This may eventually contribute to an oversupply of clergy within the DRC context.

Chaves (2001:36; see Chang 2004:16-21), as an informed academic, observes that the Protestant church is experiencing more of a distribution issue. There are enough clergy to serve in local congregations, but insufficient remuneration and a resistance to relocate to an undesirable location. This have influenced their decision to decline the call to those congregations. Resistance by Protestant clergy to relocate, is also related to the spouse's inability to gain employment in the new location as well as the higher salaries needed by mid-life or second career clergy (Chaves 2001:36-37).

According to Chang (2006), the answer to whether there is a clergy shortage is a dialectical 'yes' and 'no'. It is 'yes' when denominational leaders observe the vacancy rate in smaller churches and it is 'no' when there is a large number of clergy who are competing for the fewer better paying positions. She (Chang 2006) advocates that it is not a matter of a clergy shortage, but rather of balance. However, this is prevalent in the Protestant church and does not hold true of the Roman Catholic Church's shortage of priests. Pentecostal and charismatic (neo-Pentecostal) denominations face less of a clergy shortage; nevertheless, they do face one (Holm 2005:11).

\section{Clergy and calling}

Nel and Scholtz (2015:1) describe the change in the concept and meaning of vocation, particularly for Christians, focusing on four historical periods: the Early Church, the Middle Ages, the Reformation and the modern period. Initially vocation was a call to discipleship and community within the Early Church period which transitioned to a clergy or laity split, with only monks, priests and bishops having callings during the Middle Ages. This was followed by a reversal to all work having the dignity of a calling during the Reformation and finally, to the secularisation of the vocation concept in the modern period (Nel \& Scholtz 2015:1-2). At this point, Barth's distinction $(1961: 597,598,600)$ between calling as vocation and calling as divine summons proves useful as he considers vocation as being distinct for each person and a basis for obedience to the divine summons. While vocation may change, the divine summons does not; yet, they are not disconnected (Nel \& Scholtz 2015:4). In the Roman Catholic tradition, the call is to follow and elements of 'discernment, gifts, frustration, feeling lost, a message, service, and a new name' are 'essential to understanding vocation' (Calahan 2016:26). In the Protestant tradition the call is to follow Christ and to live in the world and this is by means of two distinct calls: a spiritual or general call to be a Christian and an external or particular call (Schuurman 2016:52, 58).

Within the above context, a clergy's call, with reference to the Christian faith, represents a divine summons to the vocation of serving God and others within the particular framework of full-time congregational ministry. Clergy are called from among the people of God towards the very same people (Nel \& Scholtz 2015:5). Nel (2002:157) raises four points concerning clergy responding to the call to fulltime congregational ministry: firstly, they realise their calling is a fulfilment of their life purpose; secondly, they are willing to pay the price required by the profession; thirdly, they are willing to be trained for the profession (initially and on-going); and fourthly, they are committed to a lifelong evaluation within the profession. The Barna Group (2017:58) notes that 'a pastor's confidence in his or her calling is correlated to how satisfied they are with their work and with their current church ministry' which shows the impact of job satisfaction in clergy calling confidence.

\section{Clergy and conflict}

There are different types of conflict, but it is not the scope of this article to comprehensively deal with all of them. Some types include relational, data, interest, structural and value conflict as found in conflict resolution theory (Mediate 2017). The different types of conflict that clergy experience include frustration with ecclesiastical and Episcopal policies, the size and concentration of the diocese and conflict with leadership (Coles 2002; Seidler 1979:763, 765).

Conflict is not a recent phenomenon. Specifically in the biblical account, one observes numerous personal and interpersonal conflicts. These include tension in the family (Cain and Abel), the seduction of power (Saul and David), partners in ministry separating over disagreement (Paul and Barnabas) and individual responses to issues and values (Paul and Peter) (Gl 2:11-12; see Hicks 2010:17-18). A useful definition of conflict in relation to the church context is given by Sande (2004:29) who states that conflict is 'a difference in opinion or purpose that frustrates someone's goals or desires'. Conflict is not necessarily destructive, however, not all conflict is neutral or constructive (Sande 2004:30). Serious conflict negatively affects church growth (Roozen 2015:3). 
This is why 'the significance of the leadership of the clergy cannot be understated when considering that conflict is an inevitable part of congregational history' (Jackson Jr. 2012:2), as effective leadership within congregations reduces the likelihood of conflict (Chou 2008:95).

According to Sande (2004) causes of conflict include:

misunderstandings resulting from poor communication ... differences in values, goals, gifts, calling, priorities, expectations, interests, or opinions ... competition over limited resources, such as time or money ... [and] sinful words, attitudes and habits that lead to sinful words and actions. (p. 30)

In a study conducted by Hoge and Wenger (2005:36-39), $53 \%$ of ministers who were surveyed that left partially or involuntary, cites conflict with staff, laity or denominational officials as their main motivation. These ministers inclined to associate conflict with a sense of loneliness and isolation (Hoge \& Wenger 2005:36-39). Nyiawung and Van Eck (2013) provide reasons why clergy often face conflict within the ministry and these include that clergy:

ignore the fact that (1) they are expected to know their mission better than anyone else; (2) the diverse backgrounds of their followers are potential causes of conflict; and (3) there are several distracting agents within the ministry. (p. 1)

They advocate a biblical model of conflict management modelled by Jesus Christ as recorded by Luke 9:18-22 (Nyiawung \& Van Eck 2013:3-5).

Spencer, Winston and Bocarnea's study (2012:91) 'confirms at least two significant areas of concern for clergy in terms of sustaining a sense of positive ministry continuance', namely vision conflict and compassion fatigue. Vision conflict describes clergy's disillusionment with the ministry considered a contributing factor to conflict in clergy (Spencer et al. 2012:86, 91-93). Clergy experience a disparity between what they expected to happen as opposed to what actually took place concerning answering the call which results in them questioning their call (Spencer et al. 2012:92). Compassion fatigue occurs when emotional reserves are depleted in the process of assisting others (Spencer et al. 2012:94). Both vision conflict and compassion fatigue 'affect the likelihood that clergy may exit the ministry' (Spencer et al. 2012:94).

According to Hoge and Wenger (2005:78) the top five issues regarding conflicts that clergy experience are 'pastoral leadership style, finances, changes in worship style, conflicts among staff or clergy, and renovation issues' (see LifeWay Research 2015b: slide 43). This was true for clergy who have left the pastorate as well as those currently in the pastorate with the only difference being that the control group of current pastors reported fewer incidents of conflict (Hoge \& Wenger 2003:79-80). Most of the conflict clergy experience is in the area of pastoral leadership style with two specific problems: firstly, innovative young pastors facing traditional 'don't-change-anything' older adults; and secondly, new pastors in churches that had just experienced long, gratifying pastorates (Hoge \& Wenger 2003:7).
Jackson Jr. (2012) highlights the effect of conflict on clergy:

Some clergy reported the toll of conflict included health concerns (high blood pressure, stroke, anxiety, and diagnosed depression), emotional concerns (degradation of trust, emotional scarring, increased sensitivities during conflict, grief, and increased effort in the struggle of managing own emotions), and vocational concerns (questioning 'calling,' taking a leave of absence, and leaving the ministry altogether). (p. 86-87)

In short, conflict contributes to the shortage of clergy. Their experiences over time either supports or diminishes the call into ministry with some considering leaving because of the 'accumulation of conflicts, struggles, unmet expectations, and difficult people' (Lee 2017:69). Prevost (2016:320) notes 'daily hassles and interpersonal conflicts have a stronger predictive effect on lower levels of wellbeing than major negative life events', while Poirier (2006:9) states that 'Christ is the reason many enter the pastorate. Conflict is the reason many leave.' It would seem that the little foxes, such as unresolved conflict, cause the most damage (Jdg 15:4-5; Can 2:15).

It is important to note that training in conflict management is inadequate at seminary level and this leaves clergy ill prepared to deal with conflict situations, difficult personalities and communication problems (Hart 1984:115; Jackson Jr. 2012:76). London Jr. and Wiseman (2003:62-63) finds that three out of ten clergy lacked conflict management training in their seminary or Bible college education, while two thirds reported that their congregation experienced a conflict during the past two years.

\section{Role conflict}

There needs to be a clarification between role ambiguity and role conflict. Role ambiguity is 'uncertainty about what the occupant of a particular office is supposed to do', while role conflict is 'the simultaneous occurrence of two or more role expectations such that compliance with one would make compliance with the other more difficult' (Katz \& Kahn 1978:206). Role conflict is one of many stressors experienced by those in the service professions (Prevost 2016:323) such as when laity and clergy expectations differ regarding clergy roles (Prevost 2016:325). One study (LifeWay Research 2015a:43) finds conflict over expectations about the pastor's role was true for $25 \%$ of the respondents. Although there seems to be no consensus regarding either the quantity or characteristics of clergy roles (Francis \& Rodger 1996:66), there have been numerous attempts to identify them. Clergy roles include administrator, organiser, pastor, preacher, priest, teacher (Blizzard 1956:508), traditional counselling, administration, community problem solving, Christian education (Nelsen, Yokley \& Madron 1973:380), a prophet (Reilly 1975), celebrant of sacraments, community leader (Francis \& Rodger 1996:70), what could be termed as equipper ('training people for ministry') and evangelist or disciplemaker ('converting others to faith') (Carroll 2006:119), and the fragmented generalist, therapist, CEO and competitor (Pillay 2012:4) - duplicate roles within these lists have been omitted. 


\section{Leadership conflict}

Aspects of leadership conflict includes the style of leadership employed by the senior person, other staff, laity and congregants. Hoge and Wenger (2003:7) list clergy conflicts in order of importance as pastoral leadership style, finances, changes in worship style, conflicts between staff or clergy, issues about new buildings or renovation and changes in music styles. LifeWay (2015a:43) finds that conflict over the pastor's leadership style was true for $27 \%$ of the respondents, particularly in the 18-44 and 45-54 age brackets.

Conflict arises when senior clergy share responsibility without sharing authority, often because they feel threatened by other staff (Bixby 2016:24). It also arises when an autocratic pastoral leadership style is used as opposed to a preferred collaborative approach (Hoge \& Wenger 2005:9). The extreme display of destructive autocratic leadership that contributes to conflict in clergy is toxic leadership that leaves the person or organisation in a worse state than before (Lipman-Blumen 2005:29).

Carroll's study (2006:131-140) identifies four specific leadership styles: firstly, the pastor takes charge; secondly, the pastor inspires members to act, but acts alone when necessary; thirdly, the pastor acts on the goals set by members; and fourthly, the members make decisions and the pastor empowers them. The majority of clergy $(75 \%)$ and half of the members $(49 \%)$ prefer the second style, while smaller numbers prefer the remaining styles (Center for Creative Ministry 2005). The first leadership style is preferred by $4 \%$ of clergy and $20 \%$ of members, the third style is preferred by $11 \%$ clergy and $15 \%$ of members, and the fourth style is preferred by $10 \%$ of clergy and $4 \%$ of members (Center for Creative Ministry 2005). When the first and second styles are grouped together, it indicates a desire for proactive clergy, and the second, third and fourth styles together indicate the desire to empower members. One can thus see that effective pastoral leadership requires balancing between taking action and empowering members (Center for Creative Ministry 2005).

\section{Congregational conflict}

Congregational conflict within this article is used to describe clergy's conflict with colleagues and congregants. Jackson Jr. (2012:71-73) states that 'clergy sometimes find themselves confronting an incongruence of mission, vision, and direction' and provides examples of clergy being challenged by associates and congregants in the areas of subversive behaviour, personal agendas contrary to church vision and manipulation via prayer meetings. Brubaker (2016) notes that 'high intensity congregational conflict is brutal on congregational leaders' and they often feel paralysed when caught therein.

Similar to people, congregations prefer to avoid conflict and are poor at dealing with it (Roozen 2015:5). Conflict can also be an obstacle to growth, especially 'serious conflict' (Roozen
2015:5). The Hartford Seminary FACT 2015 study indicates that $83 \%$ of congregations report experiencing conflict over the past five years with $29 \%$ reporting 'serious conflict' (Roozen 2015:5). Yet, some conflict is necessary for congregational growth, as those with none are less likely to grow than those with some conflict, albeit not serious conflict (Roozen 2015:5).

Jackson Jr. (2012:49-50) categorises congregational conflict into six themes: ministry direction, staffing, facilities, governance, multiple issues, and unique conflicts. He further categorises the nature of the conflict into four groups: relationship, philosophical, task-oriented, and other (Jackson Jr. 2012:50). His interviews led to the following observations: firstly, clergy sometimes face an incongruence of mission, vision and direction; secondly, clergy sometimes experience a distinct communication disadvantage; and thirdly, clergy sometimes feel unprepared to deal with conflict (Jackson Jr. 2012:58). Wilson's experience (2016) has led him to believe that:

many churches lack the basic skills and habits to manage conflict redemptively. Biblical examples and injunctions (Matt 18; Acts 6:15) are routinely ignored or rationalized away, and the resulting church conflict often leads to permanent damage to individuals and to the gospel witness. (p. 336)

The causes of congregational conflict include: the nature of the distinction between clergy and laity (Nyiawung \& Van Eck 2013:2); when congregants, advancing their own religious interests, are not satisfied; the instability of leaders; and the perceived legitimacy of leaders by congregants (Chou 2008:95-96). LifeWay Research $(2015 a: 8,41)$ finds that the second highest reason for leaving the pastorate, at $26 \%$, is conflict within the church. This is especially true of small churches with an attendance of 0-249 (LifeWay Research 2015a:89). Eighty per cent of the 1500 pastors surveyed, agreed that they would need to confront conflict within their current pastorate (LifeWay Research 2015a:10) with 75\% indicating that they had taken courses on dealing with conflict (LifeWay Research 2015a:23). As much as 90\% say they invest in processes to prevent conflict (LifeWay Research 2015a:28). In another study, over half of the respondents experienced a personal attack by a church member - resulting in one out of four clergy leaving the church because of the conflict (Rainer 2016). Unfortunately, current and unresolved conflict between a minister and members have resulted in forced terminations (Tanner 2016:2).

\section{Denominational conflict}

Denominational conflict describes the conflict that clergy experience with their denominational leaders and structures. According to Hoge and Wenger's research (2005:36), it is the second most common reason given by clergy who have left ministry for secular work. They posit that potential conflict is dependent on the degree to which a pastor's career is dependent on denomination officials (Hoge \& Wenger 2005:114). While denominational conflict is often concentrated on 'clergy sexual misconduct, homosexuality, the ordination of women, and doctrinal issues' (Carroll, McMillan \& James 
2002:3), other sources include lack of support from officials who were invested in avoiding conflict (Hoge \& Wenger 2005:36, 77, 98-99, 114), authoritarian structures that micromanage (Barna Group 2017:91), personality clashes, lack of communication and lack of collegiality. On the other hand, denominational superintendents note the following changes regarding clergy: an increase in independence and entitlement within younger clergy, considering the call of a profession, seeking a 40-hour work week, lacking a servant attitude, confusing conversion with call (particularly mid-career clergy), an increase in sexual misconduct, higher expectations from laity and a decrease in denominational loyalty that they attribute to an increased consumer-oriented culture (Hoge \& Wenger 2005:154-172). Some clergy experience conflict when their superiors disapprove of their desire to serve in a specific context (Pietkiewicz 2016:388).

\section{A classic grounded theory methodology approach}

Against the background of the above discussion, a research gap was identified in the context of the attrition of clergy in churches in South Africa and the following broad research question was formulated: Why are charismatic clergy in South Africa leaving full-time pastoral ministry? This led to a classic grounded theory exploration of pastors, trained at the Hatfield Training Centre (HTC) which is the Bible College of a Charismatic megachurch, namely Hatfield Christian Church (HCC), located in Pretoria, South Africa. Some of these pastors, after training, proceed to respond to their call at other churches - sometimes at HCC itself.

Grounded theory is a 'methodology for inductively generating theory' by means of open, selective, axial and theoretical coding of data obtained via multiple sources (Evans 2013). Open or substantive coding develops a set of categories and their properties (Evans 2013). Selective coding selects one category as a core concept and groups other codes around it. Axial coding, unique to Strauss and Corbin, is a set of procedures that use a coding paradigm to reassemble data in new ways by following open coding (Evans 2013). Theoretical coding is conceptualising 'how the substantive codes may relate to each other as hypotheses to be integrated into the theory' (Evans 2013).

Evans (2013) states that, since grounded theory's inception in 1967, it has evolved into four streams: classic grounded theory (Glaser), qualitative data analysis (Strauss), constructivist grounded theory (Charmaz) and feminist grounded theory (Wuest). Classic grounded theory, based on the original work of Glaser and Strauss in 1965 and 1967, evaluates the empirical grounding of theory by means of fit, understandability, generalisability and control. It is rigorous, flexible and post-positivistic (Evans 2013).

In this study, participants were sourced from a church-based training institution located in Pretoria, South Africa, namely HTC. Permission was granted to access student records dating back to 1989 which yielded 188 potential participants.
Research criteria and limitations for selecting participants were the following: firstly, commencement of undergraduate level theological studies at HTC; secondly, employment in a full-time pastoral capacity by a church; and thirdly, subsequently leaving full-time pastoral ministry. Ethical procedures were followed, namely obtaining informed consent, freedom to exit the study at any time without negative reprisals, assuring confidentiality, selecting venues conducive to participant safety and emotional wellbeing, and offering support where needed. Eventually the ten responding participants were all male. The sample included a few female participants, but those contacted, declined participation. Participants had been in full-time pastoral ministry as one of the following: student pastor, assistant pastor, associate pastor, pastor, congregational pastor or district pastor.

Data were collected via semi-structured interviews that were digitally recorded, transcribed, manually and software (MS Excel) coded, and compared in cyclical patterns until categories and their properties were identified. The process continued until theoretical saturation had been achieved, namely no new codes or categories emerged. It was completed with the construction of a substantive grounded theory.

Within this study, incidents contributing to clergy exiting full-time pastoral ministry were coded, that resulted in 4010 rows, 235 unique codes and seven categories. Initially, incidents seemed varied and unrelated until grouped as ministry-experience-incidents (MEI's) which could be either positive or negative in nature. Coded MEI's resulted in the discovery of a basic social process called responding to the call.

\section{Findings}

Interviews yielded 235 codes that were clustered into 12 categories. The 12 categories were used to construct a basic social process, namely 'responding to the call'. It comprised of a core category and six supporting categories. The conflict category ranked sixth with 21 codes (Joynt 2012:166, 183184). Properties of this category include conflict due to miscommunication, congregational conflict, dealing with favouritism, conflict with leadership and leaving because of conflict. Selected interview excerpts are provided to indicate its properties.

\section{Conflict due to miscommunication}

Participants expressed how a lack of clear communication resulted in friction, and in some instances, in leaving full-time pastoral ministry. Types of conflict due to miscommunication included role ambiguity, role conflict and leadership conflict:

'A lot of spoken friction between him and I [...] I just want to know who is supposed lead and who was supposed to assist [...] there was no clear communication on what was supposed to happen and how it was to happen when it comes to the leadership of that church, so I was told or at least that's the impression I got, 
that I must go there together with the gentleman that was to plant the church'. (Participant 2, male, 32 years)

\section{Conflict due to favouritism}

Some participants experienced conflict due to falling out of favour with the senior leader. The certainty with which they viewed others as 'favourites', was stark:

'You know $X X X^{1}$ always had his blue eyed boys; there was always someone on the staff whom he favoured more than others $[\ldots][W]$ hen I was just first in the ministry, XXX [senior pastor] loved me, he liked, he took me along to a conference in $Y Y^{2}$, so I had to drive the motor car, we were good friends. And then as time went on I did a couple of things wrong, I think he thought I wasn't, [an] innovator of new things, he called me, he would call me, and he would call other people that and I always classified myself as that. I'm a maintenance man. If I've got a flock and I can keep them happy and keep them motivated keep them growing then I'm doing my job'. (Participant 3, male, 76 years)

\section{Conflict with leadership}

Participants indicated experiencing conflict with senior leaders due to personality clashes, expressing a change in calling, or 'boldly standing up' to a leader:

'(Chuckle) In the first part we just bumped heads [...] Oh it was big time personality [...] Big time personality. Um, I think XXX wanted someone that would be like, I say, submissive, ' ja pastor' [yes, pastor] person'. (Participant 4, male, 40 years)

'I started to feel an increasing call, um, to mission as opposed to pastoral work. Um, which sometimes put me in conflict with the pastoral ideals of the church'. (Participant 5, male, 43 years)

'[O]ver a period of time um, a lot of times um, the senior pastor and myself we bumped um, we clashed a lot and nobody really had the boldness to stand up to him. I was maybe one of the people that did and uh, you know so we clashed, we clashed, at times'. (Participant 8 , male, 41 years)

\section{Leaving due to conflict}

Participants indicated leaving after observing conflict between others, namely the control of a senior leader over a subordinate.

'Well, when I heard him say that to the youth pastor, that's control, that is manipulation, I am not going to stand for that, I am not going to be under that. Very sorry, and at that point I also felt a release in my spirit to just go and I had a meeting. I called a meeting with him and I said, I didn't say why I was leaving'. (Participant 1, male, 35 years)

\section{Discussion}

Clergy respond to a call (Joynt 2012); other professions may consider it a response to a vocation. A number of factors hinder clergy's positive response to the call, namely conflict that contributes to their decision to leave full-time pastoral ministry. They leave because of conflict due to miscommunication,

1.XXX is used to protect the identity of the senior leader.

2.YYY is used to not identify the name of the conference which was attended. congregational and denominational conflict, dealing with favouritism and conflict with leadership.

Firstly, participants indicated they experienced a lack of clear communication resulting in conflict in relationships that contributed to their leaving of full-time pastoral ministry: Types of conflict, due to miscommunication, included role ambiguity, role conflict and leadership conflict. Role ambiguity occurred when roles and responsibilities were unclear such as lack of clarity regarding who is in charge of a specific project and who needs to be secondary. Role conflict occurred when two or more role expectations worked against each other and could not be fulfilled simultaneously such as being an 'innovator' and 'sustainer' at the same time. Clearly defined job descriptions, key performance areas and key performance indicators would assist in defining appropriate reporting practices and responsibilities as well as contribute to reducing misunderstanding regarding job roles and reporting lines.

Secondly, participants indicated that they experienced congregational conflict which contributed to their leaving of full-time pastoral ministry. Role ambiguity and role conflict also affect clergy with regard to their congregants. Congregational conflict occurs in the areas of ministry direction, staffing, facilities, governance, multiple issues and unique conflicts (Jackson Jr. 2012:49-50). Elkington's resiliency training (2013:11-12) - preparing for the personal cost of a ministry career and the value of hardship in the shaping of clergy - is recommended to navigate congregational conflict.

Thirdly, participants indicated they experienced falling out of favour with a senior leader. This is not a new challenge, as biblical examples illustrating 'falling out of favour' include Shadrach, Meshach and Abednego with Nebuchadnezzar (Dn 3:13, 19), David with Saul (1 Sm 18:8), and Paul with John Mark (Ac 15:36-41). Favouritism or preferential behaviour is a source of pastoral intragroup conflict (Breen \& Matusitz 2012:356-357) which contributes to the aspect of congregational conflict as mentioned above. Compulsory conflict management training at all levels of theological tertiary education as well as on-going continuous professional development, is recommended.

Fourthly, participants experienced conflict with leadership in the areas of personality clashes and expressing a change in calling. One participant attributed Standing up to the senior leader as a personality clash, while another described it as 'boldness' when others were too afraid to speak up. Another participant experienced conflict when he indicated that he sensed a change in calling from the pastoral to missions, as this was in conflict with the pastoral focus of the local congregation. A study by LifeWay Research (2015a:8) finds that the highest reason for leaving the pastorate, at $37 \%$, is a change in calling (the very reason given in the interview). Breen and Matusitz (2012:370) state that conflict between pastors is a serious problem. It is evident in situations where associate pastors are more independent 
and would prefer not to be ordered around and supervised (micromanaged) by the head pastor as well as when some associate pastors think that the head pastor is not sufficiently doing his or her job (Breen \& Matusitz 2012:359-360). Positive steps to deal with conflict include actively addressing it before it spins out of control, making a commitment to heal the conflict and owning one's part of the mess (Reed 2016:312). It also requires recognising that contemporary society, comprising of a majority of Millennials, is moving to a more collaborative leadership style than the Boomer's autocratic style (Brousell 2015).

\section{A practical theological lens}

Osmer's four tasks of practical theological interpretation (2008:4) are used as a lens to further explore the findings regarding the role of conflict in clergy who leave full-time pastoral ministry.

Firstly, the descriptive-empirical task gathers information that helps one 'discern patterns and dynamics in particular episodes, situations, or contexts' and assists in answering the question: What is going on? (Osmer 2008:4). There is a shortage of clergy - the study's data indicate that clergy leave full-time pastoral ministry due to various factors, including conflict because of miscommunication, congregational and denominational conflict, dealing with favouritism and conflict with leadership. These have been explained in the preceding sections.

Secondly, the interpretive task draws on 'theories of the arts and sciences to better understand and explain why these patterns and dynamics are occurring' and assists in answering the question: Why is this going on? (Osmer 2008:4). Classic grounded theory was used to discover the core category responding to the call and its various properties, including conflict in the call. Episodes (Osmer 2008:12) described ministry-experience-incidents, while situations (Osmer 2008:12) described conflict's contribution to the choice to leave, and the context (Osmer 2008:12) was full-time pastoral ministry. Role ambiguity, role conflict and other types of conflict were offered as explanations as to why conflict is taking place.

Thirdly, the normative task uses 'theological concepts to interpret particular episodes, situations, or contexts, constructing ethical norms to guide' responses and learn from good practice, and assists in answering the question: What ought to be going on? (Osmer 2008:4). There are clear indicators within the Scriptures as to what is expected from Christ-followers (Mi 6:8; Mt 28:18-20). In a similar manner, establishing clear job descriptions and reporting lines, advocating resiliency and conflict management training as well as providing training in leadership skills, will contribute to retaining clergy that equip the faith community.

Fourthly, the pragmatic task determines 'strategies of action that will influence situations in ways that are desirable and entering into a reflective conversation with the "talk back" emerging when they are enacted' and assists in answering the question: How might we respond? (Osmer 2008:4). Rainer (2016) notes that 'nearly half (48\%) of the former pastors said they had not been trained for relational and leadership issues. We hear this from current pastors and staff as well'. Strategies of action include incorporating conflict management and resiliency training at theological tertiary education level as well as on-going upskilling in these areas. Feedback from the field, in dialogue with the Scriptures, needs to inform future curriculum development.

\section{Conclusion}

Clergy play a significant role in the church. A shortage negatively affects the spiritual and numerical growth of the church as an organisation. The grounded theory study (Joynt 2012) on which this article is based, identified factors that contribute to the clergy shortage in South Africa. A basic social process responding to the call and its six properties was identified by means of the classic grounded theory. Conflict constituted one of the properties with 21 codes. Clergy left full-time pastoral ministry because of not being called in the first place, having a dual or seasonal call, and leaving due to a number of factors, including the focus of this article, namely conflict. Within the study, participants indicated that they experienced conflict due to miscommunication (Participant $2)$, falling out of favour (Participant 3) and conflict with leadership (Participant 4, 5 and 8).

The value of the study is that it identified the property conflict within the basic social process responding to the call as a contributor to clergy leaving full-time pastoral ministry. Findings correspond to Hoge and Wenger's study (2005) conducted in the USA. Limitations of the study included obtaining participants that met the required criteria of, firstly, attending HTC from 1990-2010; secondly, attaining a Bachelor of Arts degree from Global University (previously known as ICI University); thirdly, being employed within a full-time pastoral capacity at a church; fourthly, leaving; and fifthly, residing within South Africa; sixthly, the use of nonresearch specific software (Microsoft Excel) instead of ATLAS. ti or NVivo; seventhly, not representing or including all denominations or theological training institutions in South Africa; and eighthly, not determining or evaluating the preparation and training of clergy within the selected theological training institution, namely HTC.

Future research in the area of retaining clergy called to fulltime pastoral ministry, might include: firstly, investigating whether verbal and non-verbal communication skills courses are included in clergy training and whether they are effective; secondly, investigating whether $360^{\circ}$ conflict management training with regard to superiors, colleagues, staff and congregants is included in clergy training and whether it is effective; and thirdly, whether resiliency training (Elkington 2013:11-12) with regard to preparing for the personal cost of a ministry career and the value of hardship in the shaping of clergy is standard practice in clergy training and whether it is effective. There need not be an exodus of clergy. 


\section{Acknowledgements}

This article is based on a conference paper of the same title presented at the 79th Annual Meeting of the Association for the Sociology of Religion held from 12-14 August 2017 in Montreal, Canada. Both the conference paper and subsequent article focus on one of the core categories, namely conflict, of the author's PhD dissertation (University of Pretoria, Dec 2012, supervised by Prof Yolanda Dreyer). It is the third in a proposed series of conference papers and articles focusing on different categories comprising the reasons, as discovered through a grounded theory exploration, why clergy leave full-time pastoral ministry at a church.

\section{Competing interests}

The author declares that he has no financial or personal relationships which may have inappropriately influenced him in writing this article.

\section{References}

Barna Group, 2017, The state of the pastors: How today's faith leaders are navigating life and leadership in an age of complexity, Barna Group, Ventura, CA.

Barth, K., 1961, The doctrine of creation: Church Dogmatics volume III/4, transl. A.T. Mackay, eds. T.H.L. Parker, H. Knight, H.A. Kennedy \& J. Marks, Clark, Edinburgh.

Bixby, D., 2016, 'Pastor in the middle: Don't avoid conflict, avoid triangles', Christian Century 133(13), 24-26.

Blizzard, S., 1956, 'The minister's dilemma', The Christian Century 73, 508-509.

Breen, G.-M. \& Matusitz, J., 2012, 'Spiritual and religious communication: Intragroup conflict among Southern Baptist Pastors', Journal of Human Behavior in the Socia Environment 22, 351-374. https://doi.org/10.1080/10911359.2012.655612

Brousell, L., 2015, How millennials challenge traditional leadership, viewed 28 October, from http://www.cio.com/article/2956600/leadership-management/ how-millennials-792challenge-traditional-leadership.htm

Brubaker, D., 2016, Surviving congregational conflict, viewed 08 August 2017, from http://www.congregationalconsulting.org/surviving-congregational-conflict/

Cahall, L.S., 2012, 'James M. Gustafson and Catholic theological ethics', Journal of Moral Theology 1(1), 92-115.

Calahan, K.A., 2016, 'Called to follow: Vocation in the Catholic tradition', in K.A. Calahan \& D.J. Schuurman (eds.), Calling in today's world: Voices from eight faith perspectives, pp. 26-51, Wm. B. Eerdmans Publishing Co., Grand Rapids, MI.

Carroll, J.W., 2006, God's potters: Pastoral leadership and the shaping of congregations, William B. Eerdmans, Grand Rapids, MI

Carroll, J.W., McMillan, B.R. \& James Jr., J.B. 2002, Pulpit \& pew: Research on pastora leadership, viewed 28 October 2017, from http://pulpitandpew.org/sites/all/ themes/pulpitandpew/files/clergy_letter_1.pdf

Catholic Online, 2015, Shortage finds Catholic Church importing priests from Asia Africa, viewed 02 January 2017, from http://www.catholic.org/news/hf/faith/ story. php?id=60993

Center for Applied Research in the Apostolate, 2015, Frequently requested church statistics, viewed 02 January 2017, from http://cara.georgetown.edu/frequentlyrequested-church-statistics

Center for Creative Ministry, 2005, Leadership style, viewed 10 August 2017, from http://www.creativeministry.org/article/1385/coordination-communication/ leadership-style

Chang, P.M., 2004, Assessing the clergy supply in the 21st century, viewed 2 January 2017, from http://faithcommunitiestoday.org/sites/all/themes/pulpitandpew/ files/ClergySupply.pdf

Chang, P., 2006, A quick question: Is there a clergy shortage?, viewed 10 August 2017, from http://hirr.hartsem.edu/research/quick_question28.html

Chaves, M., 2001, 'Challenges for the 21st Century', The Journal of the Interim Ministry Network, Annual Review (Dec), 27-39.

Chou, H.-T.G., 2008, 'The impact of congregational characteristics on conflict-related exit', Sociology of Religion 69(1), 3-108. https://doi.org/10.1093/socrel/69.1.93

Coles, N., 2002, Ministry fallout: Can we afford it? Can we prevent it?, viewed 29 July 2017, from http://ministrytoday.org.uk/magazine/issues/24/307/

Cousins, D., 2010, Experiencing leadershift: Letting go of leadership heresies, Kindle edn., David C. Cook, Colorado Springs, United States.

De Villiers, J., 2010, Talle NG kuddes herderloos: 'n Voltydse predikant per gemeente kan binnekort ' $n$ luukse wees, viewed 03 January 2017, from http://www.wendag. $\mathrm{com} /$ forum/showthread.php/704-Talle-NG-kuddes-herderloos-amp-siening-issaambly-amp-huwelike
Elkington, R., 2013, 'Adversity in pastoral leadership: Are pastors leaving the ministry in record numbers, and if so, why?', Verbum et Ecclesia 34(1), 1-13. https://doi. in record numbers, and if so,
$\mathrm{org} / 10.4102 / \mathrm{ve} . \mathrm{v} 34 \mathrm{i} 1.821$

Evans, G.L., 2013, A novice researcher's first walk through the maze of grounded theory: Rationalization for classical grounded theory, viewed 30 October 2017, from http://groundedtheoryreview.com/2013/06/22/a-novice-researchers-first-walkthrough-the-maze-of-grounded-theory-rationalization-for-classical-grounded-theory/

Francis, L.J. \& Rodger, R., 1996, 'The influence of personality on clergy role prioritisation, role influences, conflict and dissatisfaction with ministry', in L.J. Francis \& S.H. Jones (eds.), Psychological perspectives on Christian Ministry, pp. 65-81, Gracewing Publishing, Leominster, Herefordshire.

Future Church, 2013, Facts about the priest shortage, optional celibacy, and women's roles in the church, viewed 02 January 2017, from https://www.futurechurch.org/ future-of-priestly-ministry/optional-celibacy/facts-about-priest-shortageoptional-celibacy-and

Hart, A.D., 1984, Coping with depression in the ministry and other helping professions, Word Books, Albany, NY.

Heitink, G., 2007, Een kerk met karakter: Tijd voor heroriëntatie, Kok, Kampen.

Hicks, D.Q., 2010, 'A study of the conflicts within churches that lead to the termination of pastors within the Southern Baptist Convention, accompanied by a proposal of preventive and interventional solutions', PhD thesis, Department: Seminary, preventive and interventional solut
Liberty University, Lynchburg, VA.

Hoge, D.R. \& Wenger, J.E., 2003, Experiences of Protestant ministers who left local church ministry, viewed 29 July 2017, from http://pulpitandpew.org/sites/all/ themes/pulpitandpew/files/Hoge.pdf

Hoge, D.R. \& Wenger, J.E., 2005, Pastors in transition: Why clergy leave local church ministry, Wm. B. Eerdmans, Grand Rapids, MI.

Holm, R., 2005, 'Growing up Pentecostal and the journey forward', Enrich: A Journa for Pentecostal Ministry 5(1), 11-14.

Jackson, Jr., D.L., 2012, 'Clergy's conflict management style of avoidance and life satisfaction, religious commitment, and lived experiences', PhD thesis, Department: Clinical Counseling: Teaching and Supervision Trevecca Nazarene University, Nashville, TN.

Joynt, S., 2012, 'Exodus of clergy: A practical theological grounded theory exploration', Department: Practical Theology, University of Pretoria, Pretoria, South Africa.

Katz, D. \& Kahn, R.L., 1978, The social structure of organizations, 2nd ed., John Wiley \& Sons, New York.

Lee, A.A., 2017, 'Ministry longevity, family contentment, and the male clergy family: A phenomenological study of the experience of ministry', Department: School of Behavioural Sciences, Liberty University, Lynchburg, VA.

LifeWay Research, 2015a, Despite stresses, few pastors give up on ministry, viewed 26 May 2017, from http://lifewayresearc.wpengine.com/wp-content/ uploads/2015/08/Pastor-Protection-Quantitative-Report-Final.pdf

LifeWay Research, 2015b, Pastor protection research study, viewed 28 October 2017, from http://lifewayresearch.com/wp-content/uploads/2016/01/Pastor-ProtectionFormer-Pastor-Survey-Report.pdf

Lipman-Blumen, J., 2005, 'Toxic leadership: When grand illusions masquerade as noble visions', Leader to Leader 2005(36), 29-36. https://doi.org/10.1002/ltl.125

London, Jr., H.B. \& Wiseman, N.B., 2003, Pastors at greater risk, Regal Books, Ventura, CA.

Mediate, 2017, Types of conflict, viewed 28 July 2017, from http://www.mediate. com/divorce/pg17.cfm

Milbank, J., 2008, 'Stale expressions: The management-shaped church', Studies in Christian Ethics 21(1), 117-128. https://doi.org/10.1177/0953946808089730

Mohler, A., 2016, The Briefing 05-19-16: Feminists watch closely as the Pope considers women for the diaconate in the Catholic Church, viewed 03 January 2017, from http://www.albertmohler.com/2016/05/19/the-briefing-05-19-16/

Nel, M., 2002, 'Predikante opleiding: Roeping, keuring en legitimering', Verbum et Ecclesia 23(1), 151-167. https://doi.org/10.4102/ve.v23i1.1215

Nel, M. \& Scholtz, E., 2015, 'Calling, is there anything special about it?', HTS Teologiese Studies/Theological Studies 72(4), 1-7.

Nelsen, H.M., Yokley, R.L. \& Madron, T.W., 1973, 'Ministerial roles and social actionist stance: Protestant clergy and protest in the sixties', American Sociological Review 38(3), 375-386. https://doi.org/10.2307/2094360

Nyiawung, M.D. \& Van Eck, E., 2013, 'An African hermeneutic reading of Luke 9:1822 in relation to conflict and leadership in pastoral ministry: The Cameroonian context', HTS Teologiese 69(1), 1-9. https://doi.org/10.4102/hts.v69i1.1201

Osmer, R.R., 2008, Practical theology: An introduction, Wm. B. Eerdmans Publishing Co, Grand Rapids, MI.

Percy, M., 2006, Clergy: The origin of species, The Continuum International Publishing Group, London, England.

Pietkiewicz, I.J., 2016, 'Reaching a decision to change vocation: A qualitative study of former priests' experiences', International Journal for Educational and Vocational Guidance 16(3), 379-404. https://doi.org/10.1007/s10775-015-9318-2

Pillay, J., 2012, Prestige lecture series: Christian leadership revisited? The role of the pastor in the future of South Africa: What difference can a good pastor make? viewed 06 November 2017, from https://www.ufs.ac.za/docs/librariesprovider19/ all-documents/prestige-lecture-pillay-85-eng.pdf?sfvrsn $=0$

Poirier, A., 2006, The peacemaking pastor: A biblical guide to resolving church conflict, Baker Books, Grand Rapids, MI.

Prevost, E.R., 2016, 'The problem of quality of life in ministry', Review and Expositor 113(3), 315-332. https://doi.org/10.1177/0034637316658492 
Rainer, T.S., 2016, Six things you need to know about pastors who leave their ministry, viewed 23 October 2017, from http://thomrainer.com/2016/01/six-things-youneed-to-know-about-pastors-who-leave-their-ministry/

Reed, A., 2016, 'Rooted in relationship: Longevity in congregational ministry', Review and Expositor 113(3), 303-314. https://doi.org/10.1177/0034637316659304

Reilly, M.E., 1975, 'Perceptions of the priest role', Sociological Analysis 36, 347-356. https://doi.org/10.2307/3710522

Roozen, D.A., 2015, American congregations 2015: Thriving and surviving, viewed 28 July 2017, from http://www.faithcommunitiestoday.org/sites/default/files/ American-Congregations-2015.pdf

Russell, T.B., 2016, Clergy shortage or pulpit shortage?, viewed 10 August 2017, from https://carducc.wordpress.com/2016/10/24/clergy-shortage-or-pulpit-shortage/

Salden, S., 2013, Shrinking Catholic church imports priests, viewed 12 August 2017 from http://www.spiegel.de/international/germany/priest-shortage-forcescatholic-church-to-import-preachers-to-germany-a-934804.html

Sande, K., 2004, The peacemaker, Baker Books, Grand Rapids, MI.

Schuurman, D.J., 2016, 'To follow Christ, to live in the world: Calling in a Protestant key', in K.A. Calahan \& D.J. Schuurman (eds.), Calling in today's world: Voices from eight faith perspectives, pp. 52-81, Wm. B. Eerdmans Publishing Co., Grand Rapids, MI.
Seidler, J., 1979, 'Priest resignations in a lazy monopoly', American Sociological Review 44(5), 763-783. https://doi.org/10.2307/2094527

Slatter, L., 2017, Talle personeel, leraars afgelê by NG Moreleta, viewed 20 October 2017, from http://maroelamedia.co.za/nuus/sa-nuus/talle-personeel-leraarsafgele-by-ng-moreleta/

Spencer, J.L., Winston, B.E. \& Bocarnea, M.C., 2012, 'Predicting the level of Pastors' risk of termination/Exit from the Church', Pastoral Psychology 61, 85-98. https:// doi.org/10.1007/s11089-011-0410-3

Tanner, M.N., 2016, 'Learning from clergy who have been forcibly terminated', Journal of Management, Spirituality \& Religion 14(3), 1-16.

The Irish Times, 2014, Significant drop in Irish numbers of priests and nuns, viewed 02 January 2017, from http://www.irishtimes.com/news/social-affairs/religionand-beliefs/significant-drop-in-irish-numbers-of-priests-and-nuns-1.1856113

The Scotsman, 2016, Priest shortage forces Catholic Church to train up parishioners, viewed 06 January 2017, from http://www.scotsman.com/news/priest-shortageforces-catholic-church-to-train-up-parishioners-1-4273135

Trull, J.E. \& Carter, J.E., 2004, Ministerial ethics: Moral formation for church leaders, 2nd edn., Baker Academic, Grand Rapids, MI.

Wilson, B., 2016, 'What does a healthy church look like?', Review and Expositor 113(3), 333-340. https://doi.org/10.1177/0034637316658582 